\title{
The Role Of Religious Control In Dysfunctional Audit Behavior: An Empirical Study Of Auditors Of Public Accounting Firm In Indonesia
}

\author{
Heru Sulistiyo, Diponegoro University and STIE Dharmaputra, Indonesia
} Imam Ghozali, Diponegoro University, Indonesia

\begin{abstract}
This study is an empirical study of dysfunctional audit behavior in public accounting firm in Indonesia. The objective of this study is to analyze the influence of external locus of control and professional commitment on the dysfunctional audit behavior moderated by religious control. The sample of this study is 397 accountants, working in public accounting office in Indonesia, consisting of junior accountants, senior accountants and accountant managers. The sample is selected using accidental non-random sampling. The data is in the form of emails sent to the respondents. The data is analyzed using absolute difference of moderated regression SPSS. This study employs value theory approach, especially religious value in solving problems. The result of the study shows that partially, external locus of control, professional commitment, and religious control decrease dysfunctional audit behavior. In addition, this research reveals that religious control moderates the influence of professional commitment on dysfunctional audit behavior. However, religious control is not able to moderate external locus of control in decreasing dysfunctional audit behavior.
\end{abstract}

Keywords: Value Theory; Locus of Control; Professional Commitment; Religious Control; Dysfunctional Audit Behavior

\section{INTRODUCTION}

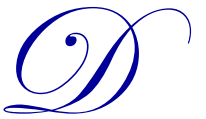

ysfunctional audit behavior is a contradicted responsibility of public accountants or auditors. Public accountants, expected to use audit standard and profession ethical code in the work, are indeed doing unethical behavior called dysfunctional audit behavior. Dysfunctional audit behavior occurs because of low ethical orientation of auditors (Ulum, 2005). Low ethical orientation declines ethical behavior, stimulating auditors to commit unethical behavior in working. Emerson and McKinney (2009); Hartman and Desjardins (2011) state that there has been a powerful devastation of ethics. Ethics, essential to be a moral foundation or values determining a particular behavior being wrong or right and the results to be good or bad, evidently, has not successfully prevented dysfunctional audit behavior. Gendron, Suddaby and Qu (2009) assert that low professional commitment and organizational commitment trigger auditors to perform dysfunctional behavior.

Some studies have been carried out to examine the effects of individual characteristics, in the forms of external locus of control and professional commitment, on the dysfunctional audit behavior. However, a general conclusion has not been provided. Several studies showed opposition results. For instance, in terms of external locus of control, Donnelly, Quirin and O'Bryan (2003); Donnelly, Quirin and O'Bryan, (2011); Marietza (2010); and Ghorbanpour, Dehnavi, and Heyrani (2014) discover the effects as positive significant. Other studies showed the effects are insignificant (Nadirsyah \& Zuhra, 2009; Paino, Pahang, Ismail \& Smith, 2011; Paino, Ismail \& Smith, 2014). On the other hand, Shapeero, Chye Koh and Killough (2003), Baskara and Ike (2011) reveal that the effects are negative significant. In terms of professional commitment, Paino, Thani, and Syid (2011) find the effects are positive significant, while 
Alkautsar (2014) discover another result. On the other hand, Indarto (2011), Silaban (2011), Amroabadi, Khanagha, and Naderibeni (2014) reveal the effects as negative significant.

Dysfunctional audit behavior is possibly avoidable if public accountants have ethical orientation capable to control behavior. Strong ethical orientation is associated with the adhered values. Strong values deriving only from God called religious values are absolute and universal in nature. Thus, public accountants, having strong religious values, are likely to have a strong self-control and able to avoid dysfunctional audit behavior. Public accountants or auditors possessing religious control are very likely to be able to control attitudes and behavior with the belief that God is omniscient and watching every action and that God provides heaven for pious individuals and hell for impious ones. Consequently, public accountants or auditors are likely to continuously strive to achieve the highest value of life, eternal life in heaven. Values achievement of secular life is not the ultimate goal, but only a medium to reach the final destination.

In every action and work in life, individuals are always guided by religion to achieve the highest value of life. Public accountants or auditors, having religious-based control are very likely to be able to avoid dysfunctional audit behavior. Based on the mentioned description, this research relates religious control in moderating the influence of external locus of control on dysfunctional audit behavior in terms of religious values. Religion is a value system derived from God, consisting regulation and prohibition for humans, resulting in the development of attitudes of self-control, selfmonitoring and self-regulation for better behavior.

\section{LITERATURE REVIEW AND HYPOTHESES}

\section{The Effects of External Locus of Control on Dysfunctional Audit Behavior}

This research relates external locus of control with dysfunctional audit behavior using value concept approach. The value system adhered by an individual and the perception of an individual in defining the good and bad, right and wrong, are likely to influence attitudes and behavior in organizational matter (Siagian, 2012). Rotter (1966) defines locus of control as an individual's perception of the source of fate. If an individual has a perception that fate comes from his own-self, it is called internal locus of control. Conversely, if an individual believes that fate comes from outer forces, luck, and blessing, it is called external locus of control.

This paper uses moderation model instead of mediation model frequently used in earlier studies. Religious control variable has a role as a moderator to see the influence of external locus of control and professional commitment on dysfunctional audit behavior. Moderating variables are usually the variables coming from outer part of examined individuals and are uncontrolled in nature (Baron \& Kenney, 1986).

Religious control is chosen as the moderating variable because in earlier studies, it has been proven that religious behavior and practice influence the increase of self-monitoring, self-control and self-regulation, and the decrease in deviant social behavior. Such attitudes emerge in connection with the belief that there is a supreme power watching them, that is God (Emerson \& McKinney, 2009; Carter, McCullough \& Carver, 2012). Moreover, Kay, Gaucher, McGregor and Nash (2010) reveals that God, as a source of external control and religious beliefs are possibly functioning as an external control, replacing manipulation when personal control is low or reduced. In addition, Hickss and King (2008) reveal that religious commitment moderates the relation between both mood and positive effect and meaning in life. The relation of those variables is caused by the existence of heaven and hell. Heaven and hell become the motivation in an individual's life. An individual is likely to be motivated to reach heaven by obeying the command of God and not wanting to live in hell by avoiding the prohibition of God.

Furthermore, Shamsudin, Chauhan and Maitama (2012) reveal that self-control is a moderation of the relation between formal control system and deviation in workplace. Audit standard and ethical code of accountants or auditors are the formal control system managing accounting behavior in performing the profession.

Accordingly, external locus of control and dysfunctional audit behavior are related in terms of values. If the value system adopted by an auditor strengthens the luck and blessing, dysfunctional audit behavior is very likely to decline. The auditor then is presumed to continuously maintain the value and is expected to avoid any deviant behavior. In 
their study, Shapeero et al. (2003), Baskara and Ike (2011) discover that external locus of control has negative influence on dysfunctional audit behavior, meaning that if locus of control increases the dysfunctional audit behavior is likely to decline.

H1: External locus of control has negative effects on dysfunctional audit behavior.

\section{The Effect of Professional Commitment on Dysfunctional Audit Behavior}

This study also connects professional commitment with dysfunctional audit behavior in the concept of value. Values, as the foundation in understanding behavior and motivation of individuals, are important in studying organizational behavior because perception is affected. In short, values influence attitudes and behavior (Robbin \& Judge, 2013). Besides, Aranya, Pollock and Amernic (1981) state that professional commitment is a belief and acceptance of objectives and values of profession, a willingness to use serious efforts for the sake of profession, a desire to maintain membership in profession. Bryan, Quirin and Donnelly (2011) argue that quality of audit is highly affected by dysfunctional audit behavior and thereby resulting in a failure of audit disclosure. The behavior of reducing the quality of audit resulting in an audit failure is an unethical behavior unsuited to the values of profession because the reputation of profession is likely to be damaged.

Accordingly, professional commitment and dysfunctional audit behavior are related in terms of values. If an auditor performs high professional commitment, there is a high possibility that the attachment and profession value upholding is likely to be high and deviant behavior is prospective to be avoided. Thus, the higher the auditor's professional commitments, the lower the dysfunctional audit behavior is expected to be, or further, dismissed.

Indarto (2011), in her study, reveals that professional commitment has negative significant effects on dysfunctional audit behavior, proxied by premature signing-off of audit procedures. Moreover, Silaban (2011) discovers that affective professional commitment and normative professional commitment, individually, have negative significant effects on the reduction of audit quality. Likewise, normative professional commitment negative significant effects on under-reporting time.

In addition, Amroabadi et al. (2014) suggest that professional commitment negatively affects audit dysfunctional behavior, meaning that the higher the auditors' performance of professional commitment, the less the dysfunctional audit behavior is likely to be. Gendron, et al. (2009) reveals that the lack of professional commitment performed by auditors is the cause of dysfunctional audit behavior. Based on the assumption that dysfunctional audit behavior is an unethical behavior unsuited with profession values, auditors with high professional commitment tend to avoid dysfunctional audit behavior.

H2: Professional commitment has negative effects on dysfunctional audit behavior.

\section{Religious Control, External Locus of Control, and Dysfunctional Audit Behavior}

Religion serves to reduce and further, to prevent deviant behavior, such as vandalism, theft, drug abuse, premarital sex, rape or assault and weapons misuse. The prevention is possible because an individual possessing high religious value is very likely to have a strong self-control as taught by religion. The role of religion in preventing deviant behavior is asserted by Cohran (1988), Shyan Fam, Waller and Zafer Erdogan (2004), Desmond, Ulmer and Bader (2013). In line with this, Casey (2009) concludes that if religion is practiced by a large number of individuals, then the benefits would accrue for the society as a whole.

In their study, Carter et al. (2012) suggest that more religious individuals tend to perform self-monitoring to a higher level reaching self-control. Furthermore, Emerson and Mckinney (2009) assert that religion teaches a belief that God is omniscient, observing all human activities, resulting in unethical behavior to be avoidable. Religion is essential to develop ethical business behavior.

McCullough and Willoughby (2009), in their study reveal that at least there are six conclusions regarding the roles of religion in the terms of increasing self-control, directing the selected, pursued and organized objectives, facilitating 
self-monitoring, encouraging self-regulatory development, regulating and encouraging the construction of a set of self-regulatory behavior, effecting the health, welfare, and social behavior caused by self-control and self-regulatory.

Carter et al. (2012) reveal that more religious individuals tend to perform self-monitoring to a higher level reaching self-control. Religious individuals tend to believe that there is a supreme power that is watching them (monitoring by God), fostering self-monitoring and self-control. Likewise, Kay, et al. (2010) reveals that God, as a source of external control and religious belief, is able to function as a form of external control, replacing the manipulation when personal control declines. Cohran (1988) have examined the attitude of religiosity in three Midwestern states USA, showing that religiosity reduce and even prevent deviant behavior, such as vandalism, theft, drug abuse, premarital sex, rape or assault and weapons misuse.

Shyan Fam et al. (2004) has investigated the influence of religious attitudes on social and consumption behavior in six countries (Malaysia, Turkey, Taiwan, China, Britain and New Zealand). These countries represent Islam, Buddhism and Christianity. The results show that deviant social and consuming behavior are possible to be reduced by increasing religious attitude. Casey (2009) has studied the psycho-social benefits of religion practice in terms of helping to reduce suicide, to reduce risk of depression, to overcome grief, to add life expectancy, to stabilize marital life and to recover from illness. Dyreng, Hanlon and Maydew (2010), Dyreng, Mayew and Williams (2012) discovers that managers of a company with high religious obedience are likely to perform less significant deviance. In addition, compared to in secular areas, in religious areas there are less frequent activities of tax evasion (tax sheltering) and there are much transparency in voluntarily delivering bad news.

Hicks and King (2008) reveal that religious commitment moderates the relation between both mood and positive effect and meaning in life. The relation of those variables is caused by the existence of heaven and hell. Heaven and hell become the motivation in an individual's life. An individual is likely to be motivated to reach heaven by obeying the command of God and not wanting to live in hell by avoiding the prohibition of God.

The existence of heaven and hell has been tested being influential in increasing the meaning of life and mood by Hicks and King (2008). Furthermore, in their study, it is revealed that religious commitment moderates the relationship between positive effects and the meaning of life. In addition, religious commitment also moderates the relationship between mood and the meaning in life.

Moderation religious commitment strengthening the relationship between variables is caused by the existence of heaven. Conversely, moderation religious commitment weakening the relationship between variables is caused by the existence of hell. In conclusion, external locus of control can be connected to religious control. Auditors with external locus of control, possessing religious control, are very likely to be continuously obedient to the rules and to avoid deviant behavior. Dysfunctional audit behavior is a behavior that could damage the reputation of auditors.

H3: Religious control negatively affects dysfunctional audit behavior.

H4: Religious control moderates external locus of control resulting in a decrease in dysfunctional audit behavior.

\section{Religious Control, Professional Commitment, and Dysfunctional Audit Behavior}

This study connects religious control in moderating the effects of professional commitment on dysfunctional audit behavior based on religious values. Parliament of the World's Religions (1993) has declared the need of religion community interdependence in the world to have universal objective of remembering the spiritual power of religion offering belief, meaning, or basic value and highest standard. In harmony with this, International Labour Organization (2012) declares that the spiritual and religious values could be the common ground to inspire and to guide the upcoming action in of globalization era. Spiritual and religious value becomes an important aspect in performing fair globalization. Strong spiritual and religious value has an important role for the correlation of work, social justice and peace.

Public accountants in conducting their profession services have responsibility not only on service providers, but also on the information users of service. Public accountant professionalism depends on the level of public confidence in 
the quality of services provided. Brammer, Williams and Zinkin (2007) discovers the role of religion on corporate social responsibility in 20 countries worldwide. More religious individuals are bound to hold broader corporate social responsibility compared to less religious individuals. Emerson and McKinney (2009) reveal that Christian professional religiosity in the USA shows an essential role in developing business attitude, especially in consideration of more ethical decision-making.

McGuire, Omer and Sharp (2011) have examined the relationship between religiosity and the decision of sustainable going concern audit opinion at public accounting firms in the USA metropolitan. The result shows that the religiosity of non-big-four auditors affects the business continuity disclosure on the audit opinion and that it has an accurate prediction of bankruptcy.

The role of religious values is evidently shown in Islamic financial institutions implementing Islamic prohibition law of usury. Responding to this phenomenon, accounting profession has developed accounting standards of Islamic banks financial. Moreover, accounting standards and audit of Islamic financial institutions have been developed by the Accounting and Auditing Organization for Islamic Financial Institutions (AAOIFI). It is the effect of religious values on accountant profession commitment in response to Islamic law implementation. The mentioned explanations show that religion affects professional commitment. Accordingly, auditors being committed to profession and possessing religious control are likely to be continuously obedient to the rules and to avoid deviant behavior. Damaging behaviors are likely to be avoided as well.

H5: Religious control moderates the effects of professional commitment resulting in a decrease in dysfunctional audit behavior.

\section{CONCEPTUAL MODEL}

The research gap presented in this study was the effects of locus of control and professional commitment on dysfunctional audit behavior. Gendron, et al. (2009) states that the lack of auditor commitment is the cause of dysfunctional audit behavior. The model of this study adds a variable of religious control with reasons mentioned in previous sections. Therefore, there were three predictor variables and one dependent variable. The variables used were connected based on the concept of value, especially religious value.

Figure 1. Research Model

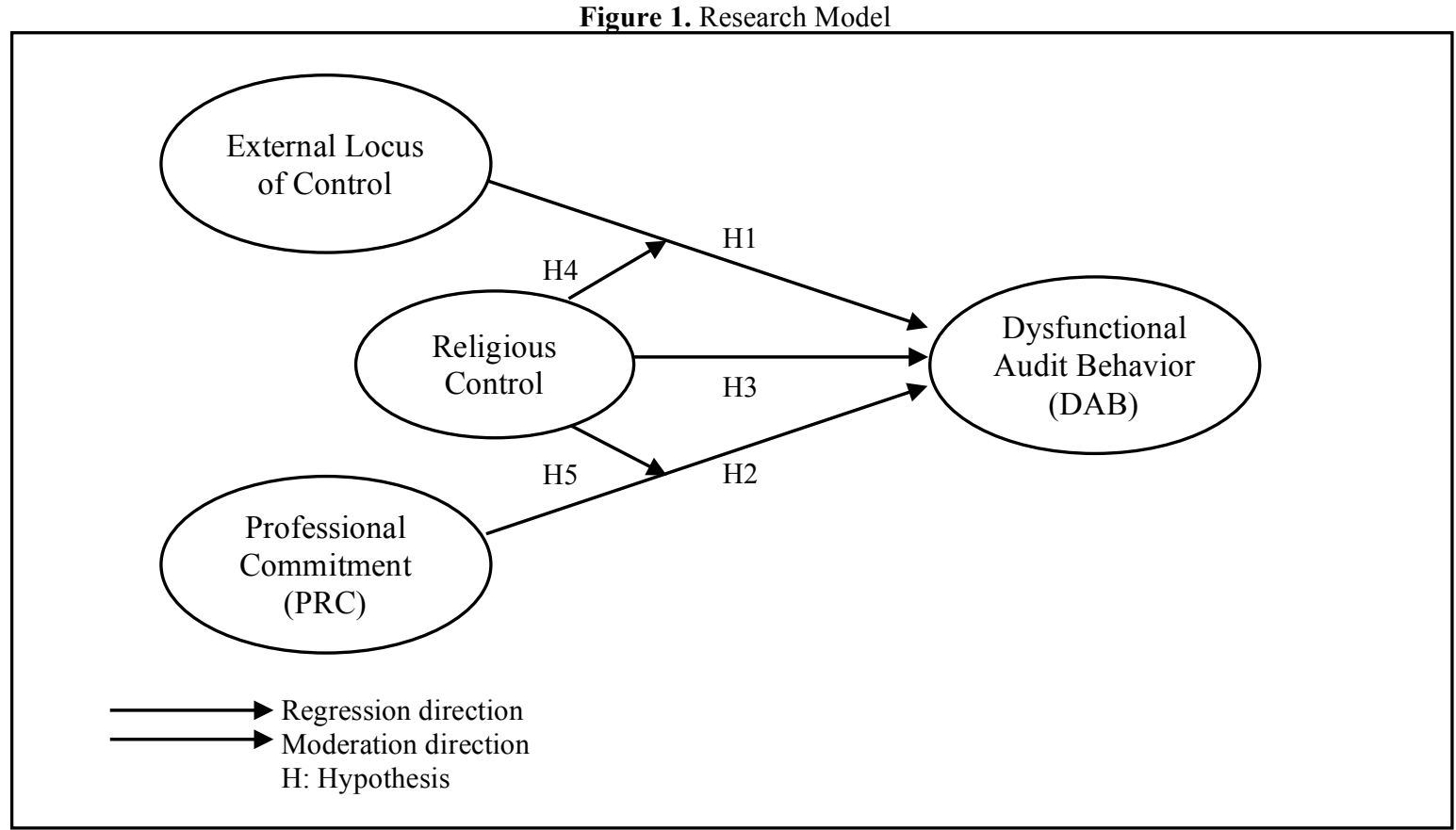


Individuals with external locus of control, believing in religious values, are likely to develop self-control, selfmonitoring and self-regulation. Therefore, dysfunctional audit behavior is possible to be avoided. Auditors, possessing professional commitment and believing that religious control strengthen the profession value, are likely to develop self-control, self-monitoring and self-regulation. Thus, dysfunctional audit behavior is possible to be avoided.

\section{METHODOLOGY}

\section{Data, Population, and Sample}

The population in this study was all auditors working on public accounting firms in Indonesia. The number and identity of the auditors were not certainly known because there was no supporting reference. Therefore, the sample was determined by accidental non-random sampling using questionnaire answers sent by email beforehand. The emails were sent to 307 public accounting firms of which each firm was allowed to provide more than one answer depending on the auditors' willingness to answer. There were 236 firms responding emails with 414 answers. After having tested for the normality and outliers, 397 answers remained, containing answers from 51 (13\%) junior auditors, 195 (49\%) senior auditors, and $151(38 \%)$ manager auditors.

\section{Validity Testing}

Research questionnaires were tested in public accounting firms in Semarang city prior distributed to the respondents. Among sent questionnaires, 35 questionnaires returned and were checked the validity and reliability using SPSS version 17 . The reliability of the questionnaires was evaluated using cronbachs alpha with the cut off value $>0.7$. The questionnaire is reliable to be an indicator of a construct if the value of cronbach alpha is greater than 0.7 (Ghozali, 2011).

Table 1. Questionnaire Reliability Testing

\begin{tabular}{l|c|c}
\hline \multicolumn{1}{c}{ Constructs } & Cronbachs Alpha Value & Status \\
\hline Locus of Control (LC) & 0.870 & Reliable \\
\hline Professional Commitment (PC) & 0.945 & Reliable \\
\hline Religious Control (RC) & 0.955 & Reliable \\
\hline Dysfunctional Audit Behavior (DAB) & 0.952 & Reliable \\
\hline
\end{tabular}

Table 1 showed that the value of Cronbach alpha is greater than 0.7 for all constructs, meaning that all constructs had been supported by the indicators in the reliable questionnaires.

The validity of the questionnaires was tested using comparison between the results correlation and the table correlation. If the results correlation is above table correlation, then the questionnaires were valid to be the indicator of the construct (Ghozali, 2011).

Table 2. Questionnaire Validity Testing

\begin{tabular}{l|c|c|c}
\hline \multicolumn{1}{|c}{ Indicators } & $\begin{array}{c}\text { Corrected Item- } \\
\text { Total Correlation }\end{array}$ & $\begin{array}{c}\text { R table (5\%, df 35, } \\
\text { two-tail) }\end{array}$ & Status \\
\hline Locus of Control (LC1 to LC10) & $0.356-0.730$ & 0.3246 & Valid \\
\hline Professional Commitment (PC1 to PC8) & $0.673-0.901$ & 0.3246 & Valid \\
\hline Religious Control (RC1 to RC16) & $0.605-0.906$ & 0.3246 & Valid \\
\hline Dysfunctional Audit Behavior (DAB1 to DAB12) & $0.522-0.855$ & 0.3246 & Valid \\
\hline
\end{tabular}

Table 2 showed that the value of corrected item total correlation of each construct was greater than $\mathrm{r}$ table $(5 \% \mathrm{df} 35$, two-sided) 0.3246 and the significance level of correlation between indicators total construct was $<0.05$. Thus, each indicator was valid in developing the constructs. 


\section{Variable Measurement}

\section{External Locus of Control}

Locus of control is a concept developed by Rotter (1966), classifying individuals into two categories in the forms of external, individuals believing that an occurrence is controlled by outer forces such as fate or luck and under control of other forces; and internal, individuals believing that they have control over the happening events.

The locus of control mentioned in this study was external locus of control measured by a single indicator in terms of relying on other forces or luck. Further, the indicator was measured using 10 items adopted from Donnelly et al. (2003). All items were measured employing Likert scale ranging from strongly disagree/ very low (1) to strongly agree/ very high (7). High scores indicated individuals having external locus of control and low scores indicated individuals having internal locus of control.

\section{Professional Commitment}

Professional commitment is a belief and acceptance of objectives and values of profession, a willingness to use serious efforts for the sake of profession, a desire to maintain membership in profession (Aranya et al., 1981). Suddaby et al. (2009) examine professional commitment by measuring the relative force to identify the involvement of an individual's profession and analyze the extent to which a member concerned, dedicated to express and be proud being a member of a profession.

Based on the explanation above, professional commitment consisted of four indicators in the form of the connection of auditors' profession values and objectives; the serious effort for sake of profession; the pride of the profession; and the determination of being auditors. The indicators were measured using 8 items adopted from Aranya et al. (1981) and Suddaby, et al. (2009). All items were measured employing Likert scale ranging from strongly disagree/ very low (1) to strongly agree/ very high (7).

\section{Religious Control}

Religious control variable is the synthesis of the concept of employee commitment, locus of control and religious value. Religious control is intended to be a religious controller of an individual derived from environment affecting the religious attitude and behavior. The indicators of religious control are suggested from several sources. Religious individuals tend to believe that there is a supreme power that is watching them (monitoring by God), fostering selfmonitoring and self-control (Carter, et al., 2012). Emerson and Mckinney (2009) reveal that religions teach a belief that God is omniscient and observing all human activities, causing unethical behavior avoided. Kay et al. (2010) reveals that God, as a source of external control and religious belief, is able to function as a form of external control, replacing the manipulation when personal control decreases. Hicks and King (2008) place heaven and hell to be the motive in an individual's life. An individual is likely to be motivated to reach heaven by obeying the command of God, and does not want to live in hell by avoid the prohibition of God.

Extrinsic religiously oriented individuals come to a place of worship to obtain social support and to lighten personal problems (Allport \& Ross, 1967). These individuals tend to benefit the religions and to develop a selective religion fitting their needs. Religion is useful to support the self-confidence, to restore the status, to survive against reality, or to give sanction of living. Dyreng et al. (2010) argues that the enterprise managers with high religious adherence showed less deviation. In addition, compared to in secular areas, in religious areas there are less frequent activities of tax evasion (tax sheltering) and there is much transparency in voluntarily delivering bad news.

The ideological and ritualistic dimension in an individual's religion. Ideological dimension relates to belief in the form of God, angels, heaven, and so on (Ancok \& Suroso, 2011). Ritualistic dimension associates with a number of behavior defined by religion, such as the acts of worship, baptism, confession, fasting, praying or performing special rituals at certain times. Other factors determining an individual's value system are parents, family, school, community, friends and one's own self (Siagian, 2012). Based on the explanation above, indicators and items to measure religious control 
were developed. All items were measured employing Likert scale ranging from strongly disagree / very low (1) to strongly agree / very high (7).

\section{Dysfunctional Audit Behavior}

Dysfunctional audit behavior is the behavior of an auditor, directly and indirectly reducing the quality of audit and resulting in a failure (Donnelly et al., 2003). Dysfunctional audit behavior consists of three types of behavior in terms of premature sign off, audit procedure alteration and deduction, and underreporting of time (Bryan, Quirin, \& Donnelly, 2011). Based on the dysfunctional audit behavior indicators proposed by Bryan et al. (2011), Likert scale ranging from strongly disagree/ very low (1) to strongly agree or very high (7) was used to measure the items.

In this study, only the level of acceptance of the auditor in dysfunctional audit behavior was investigated because the attitude of auditors in accepting a behavior is likely to influence the behavior. It is assumed that auditors accepting dysfunctional audit behavior are likely to have high potential to perform this behavior. In addition, the respondents tend to be hesitant to admit, afraid of others knowing that they had committed dysfunctional audit, causing the response to be limited or invalid.

\section{Data Analysis Methodology}

The data analysis method used in this study was absolute difference moderation using SPSS to process the data. An equation derived on the empirical research model was developed.

$\mathrm{DAB}=\beta_{1} \mathrm{LC}+\beta_{2} \mathrm{PC}+\beta_{3} \mathrm{RC}+\beta_{4} \mathrm{LC} \_\mathrm{RC}+\beta_{5} \mathrm{PC} \_\mathrm{RC}+\mathrm{Z}$

in which:

$\mathrm{DAB}=$ dysfunctional audit behavior

$\mathrm{LC}=$ external locus of control

$\mathrm{PC}=$ professional commitment

$\mathrm{RC}=$ religious control

LC_RC $=$ absolute difference between religious control and external locus of control

PC_RC $=$ difference between religious control and professional commitment

$\beta$ : regression coefficient

z: disturbance term or error

\section{RESULTS}

\section{Reliability and Validity Testing}

Prior to analysis, the questionnaires were tested in the aspects of validity and reliability using SPSS version 17 . The reliability was tested using cronbachs alpha with the cut-off value $>0.7$.

Table 3. Construct Reliability Testing

\begin{tabular}{l|c|c}
\hline \multicolumn{1}{c}{ Constructs } & Cronbachs Alpha Value & Status \\
\hline Locus of Control (LC) & 0.873 & Reliable \\
\hline Professional Commitment (PC) & 0.879 & Reliable \\
\hline Religious Control (RC) & 0.947 & Reliable \\
\hline Dysfunctional Audit Behavior (DAB) & 0.972 & Reliable \\
\hline
\end{tabular}

Table 3 showed that cronbach alpha values were above 0.7 for all constructs, meaning that all tested constructs were supported by the indicators in the reliable questionnaires. 
The validity of the questionnaires was tested using comparison between the results correlation and the table correlation.

Table 4. Construct Indicator Validity Testing

\begin{tabular}{l|c|c|c}
\hline \multicolumn{1}{|c|}{ Indicators } & $\begin{array}{c}\text { Corrected Item- } \\
\text { Total Correlation }\end{array}$ & $\begin{array}{c}\text { R table (5\%, df 397, } \\
\text { two-sided) }\end{array}$ & Status \\
\hline Locus of Control (LC1 to LC10) & $0.364-0.741$ & 0.1129 & Valid \\
\hline Professional Commitment (PC1 to PC8)) & $0.500-0.781$ & 0.1129 & Valid \\
\hline Religious Control (R1 to R 16) & $0.361-0.784$ & 0.1129 & Valid \\
\hline Dysfunctional Audit Behavior (DA1 to DA12) & $0.790-0.898$ & 0.1129 & Valid \\
\hline
\end{tabular}

Table 4 showed that the value of corrected item total correlation of each construct is greater than $\mathrm{r}$ table $(5 \%$ df 397 , two sided) 0.1129 . Thus, each indicator was valid in developing the constructs.

\section{Regression Classical Assumption Testing}

Classical assumption test results indicated that the data was normal. It was indicated by the data spreading around diagonal line and the data spreading inside curve. The autocorrelation of problem-free data was indicated by Durbin Watsons value 1.833. The multicollinearity of problem-free data was indicated by the tolerance value less than 1 and VIFless than 10 . The heteroscedasticity of problem-free data was indicated by the data unevenly spreading below and above the line of origin.

\section{Fit Model Testing}

Fit model was indicated by the value of $\mathrm{F}$ on significance of $0.000<0.05$. In addition, the proportion of Adjusted $\mathrm{R}$ square was 0.477 , meaning that the external locus of control and professional commitment explained the $47.7 \%$ of the influence on the dysfunctional audit behavior, while the remaining $52.3 \%$ was explained by other variables outside the model.

\section{Hypothesis Testing}

The analysis proved that external locus of control reduces dysfunctional audit behavior, indicated by TLC coefficient -0.126 and significance level $0.001<0.05$. The negative sign of the coefficient indicated that in case of external locus of control increases, dysfunctional audit behavior is likely to decline. The results were also supported by the descriptive of external locus of control in neutral level, indicated by average score 3.76 of score range 1 to 7 ; and dysfunctional audit behavior in a moderate level, indicated by average score 2.72 of score range 1 to 7 . If the two variables are connected, the external locus of control at neutral level is possible to decrease dysfunctional audit behavior in a moderate level. Auditors with external locus of control, believing that dysfunctional audit behavior does not fit the adhered values are likely to avoid dysfunctional audit behavior. This result supports the research of Shapeero et al. (2003), Baskara and Ike (2011).

Table 5. Hypothesis Testing

\begin{tabular}{l|c|c}
\hline \multicolumn{1}{c|}{ Hypotheses } & Coefficient & Sig. \\
\hline H1: External locus of control has negative effects on dysfunctional audit behavior. & -0.126 & 0.001 \\
\hline H2: Professional commitment has negative effects on dysfunctional audit behavior. & -0.286 & 0.000 \\
\hline H3: Religious control negatively affects dysfunctional audit behavior. & -0.444 & 0.000 \\
\hline $\begin{array}{l}\text { H4: Religious control moderates external locus of control resulting in a decrease in dysfunctional } \\
\text { audit behavior. }\end{array}$ & -0.159 & 0.000 \\
\hline $\begin{array}{l}\text { H5: Religious control moderates the effects of professional commitment resulting in a decrease } \\
\text { in dysfunctional audit behavior. }\end{array}$ & -0.005 & 0.900 \\
\hline
\end{tabular}


The result of the testing proved that professional commitment decreases dysfunctional audit behavior indicated by professional commitment (PC) coefficient -0.286 and significance level $0.000<0.05$. The negative sign of the coefficient indicated that in case of professional commitment increases, the dysfunctional audit behavior is likely to decline. The result was also supported by the descriptive of professional commitment in a high level, indicated by average score 5.01 of score range 1 to 7 ; and dysfunctional audit behavior in a moderate level, indicated by average score 2.72 of score range 1 to 7 . If the two variables are connected, the professional commitment at high level is likely to reduce dysfunctional audit behavior in a moderate level. Auditors with high professional commitment will retain the professional values. Therefore, the behavior declining professional values are likely to be avoided. This result supports the research of Indarto (2011), Silaban (2011), Amroabadi et al. (2014).

The result indicated that religious control degenerates dysfunctional audit behavior proven by TPC coefficient -0.444 and significance level $0.000<0.05$. The negative sign of the coefficient indicated that in the case of the religious control improved, the dysfunctional audit behavior is likely to decline. The result was also supported by the descriptive of religious control in a high level, indicated by average score 4.67 of score range 1 to 7 ; and dysfunctional audit behavior in a modest level, indicated by average score 2.72 of score range 1 to 7 . If the two variables are connected, the religious control at a high level is possible to decrease dysfunctional audit behavior in a moderate level. Auditors with high professional commitment will retain the professional values. Therefore, behavior that lowers the professional values is likely to be avoided. Auditors with a high religious control are likely to avoid behavior incompatible with religious values in works. Those auditors are also likely to avoid deviating behavior of the works. The research results support the research of Cohran (1988), Shyan Fam et al. (2004), Kay et al. (2010), Dyreng et al. (2010), Desmond et al. (2013).

Furthermore, the findings of this study proved that religious control reduces the effect of professional commitment in reducing dysfunctional audit behavior indicated by TPC_TRC coefficient -0.159 and significance level $0.000<0.05$. The negative sign of the coefficient indicated that in case of religious control is improved; professional commitment is likely to be improved as well, resulting in the decrease in dysfunctional audit behavior. The result was also supported by the descriptive of religious control in a high level, indicated by average score 4.67 of score range 1 to 7 ; professional commitment in a high level, indicated by average score 5.01 of score range 1 to 7 ; and dysfunctional audit behavior in a moderate level, indicated by average score 2.72 of score range 1 to 7 . If the three variables are connected, the religious control in high level increases professional commitment causing dysfunctional audit behavior to decline in a moderate level. Auditors with high professional commitment will retain the professional values. This result supports the research of Hicks and King (2008).

This study failed to prove that religious control moderate external locus of control in reducing dysfunctional audit behavior indicated by the negative effect in TLC_TRC coefficient -0.005 and significance level $0.900>0.05$. The result was also supported by the descriptive of religious control in a high level, indicated by average score 4.67 of score range 1 to 7 ; external locus of control in a high level, indicated by average score 3.76 of score range 1 to 7 ; and dysfunctional audit behavior in a moderate level, indicated by average score 2.72 of score range 1 to 7 . If the three variables are connected, the religious control in a high level is not able to increase external locus of control in the neutral state in order to decrease dysfunctional audit behavior in a moderate level. Auditors with high professional commitment will retain the professional values. This result supports the research of Hicks and King (2008).

\section{CONCLUSION}

This study partially shows that external locus of control decreases dysfunctional audit behavior. Professional commitment decreases dysfunctional audit behavior. Religious control decreases dysfunctional audit behavior and moderate the professional commitment effects on reducing dysfunctional audit behavior. Thus, the main objective of this study stating that religious control decreases dysfunctional audit behavior is proven. On the other side, the hypothesis stating that religious control moderates external locus of control reducing dysfunctional audit behavior was not proven.

\section{LIMITATION AND SUGGESTION}

Religious control analyzed in this study was focused on the external part of the auditors, in the form of environment. It means that in terms of individual characteristics, the study is not complete because the internal part was not examined 
as well. It is necessary to further study the internal locus of control of the auditors. Therefore, the study of the effects of religious control on dysfunctional audit behavior will be complete.

\section{AUTHOR BIOGRAPHIES}

Heru Sulistiyo is a lecturer at STIE Dharmaputra, Semarang. He received the doctoral degree at Accounting Studies from Diponegoro University, Semarang under the supervision of Imam Ghozali. His research focus includes behavioral accounting, locus of control and dysfunctional audit behavior.

Imam Ghozali, is a Professor of Accounting at the Faculty of Economics and Business at Diponegoro University, Semarang. He graduated with a Bachelor of Economics degree majoring in Accounting at Gadjah Mada University, Yogyakarta 1985. He completed his postgraduate education at the University of New South Wales, Sydney, Australia in 1990 and received a PhD degree in Management Accounting from the University of Wollongong, Australia in 1995.

\section{REFERENCES}

Alkautsar, M. (2014). Locus of Control, Commitment Professional and Dysfunctional Audit Behaviour. International Journal of Humanities and Management Sciences (IJHMS) 2(1), 35-38.

Allport, G. W., \& Ross, J. M. (1967). Personal religious orientation and prejudice. Journal of Personality and Social Psychology, 5(4), 432-443.

Amroabadi, M. S., Khanagha, J. B., Naderibeni, M. (2014). Professional commitment on dysfunctional audit behaviour in audit organizations of Isfahan public accountancy. Interdisciplinary Journal of Contemporary Research in Business 5(9), 276-283.

Ancok, D. \& Suroso, F., N. (2008). Psikologi Islam; Solusi Islam atas problem-problem psikologi, Yogyakarta: Pustaka Pelajar.

Aranya, N., Pollock, J., \& Amernic, J. (1981). An examination of professional commitment in public accounting. Accounting, Organizations and Society, 6(4), 271-280.

Baron, R. M., \& Kenny, D. A. (1986). The moderator-mediator variable distinction in social psychological research: Conceptual, strategic, and statistical considerations. Journal of personality and social psychology, 51(6), 1173.

Baskara, A. E., \& Ike, S. (2011). Penerimaan auditor atas dysfunctional audit behavior (Studi Empiris Pada Kantor Akuntan Publik di Jawa Tengah). MAKSI, 11(1), 1-17.

Brammer, S., Williams, G., \& Zinkin, J. (2007). Religion and attitudes to corporate social responsibility in a large cross-country sample. Journal of Business Ethics, 71(3), 229-243.

Bryan, D. O., Quirin, J. J., \& Donnelly, D. P. (2011). Locus of control and dysfunctional audit behavior. Journal of Business \& Economics Research (JBER), 3(10).

Carter, E. C., McCullough, M. E., \& Carver, C. S. (2012). The mediating role of monitoring in the association of religion with self-control. Social Psychological and Personality Science, 3(6), 691-697.

Casey, P. (2009). The psycho-social benefits of religious practise. Dublin, Ireland; Iona Institute.

Cochran, J. K. (1988). The effect of religiosity on secular and ascetic deviance. Sociological Focus, 21(4), 293-306.

Desmond, S. A., Ulmer, J. T., \& Bader, C. D. (2013). Religion, self control, and substance use. Deviant Behavior, 34(5), 384406.

Donnelly, D. P., Quirin, J. J., \& O'Bryan, D. (2003). Auditor acceptance of dysfunctional audit behavior: An explanatory model using auditors' personal characteristics. Behavioral research in accounting, 15(1), 87-110.

Donnelly, D. P., Quirin, J. J., \& O'Bryan, D. (2011). Attitudes toward dysfunctional audit behavior: The effects of locus of control, organizational commitment, and position. Journal of Applied Business Research (JABR), 19(1).

Dyreng, S. D., Mayew, W. J., \& Williams, C. D. (2012). Religious social norms and corporate financial reporting. Journal of Business Finance \& Accounting, 39(7-8), 845-875.

Dyreng, S. D., Hanlon, M., \& Maydew, E. L. (2010). The effects of executives on corporate tax avoidance. The Accounting Review, 85(4), 1163-1189.

Emerson, T. L., \& Mckinney, J. A. (2009). Importance of religious beliefs to ethical attitudes in business. Journal of Religion and Business Ethics, 1(2), 1-15.

Gendron, Y., Suddaby, R., \& Qu, S. Q. (2009). Professional-organisational commitment: A study of canadian professional accountants. Australian Accounting Review, 19(3), 231-248.

Ghorbanpour, Z., Dehnavi, H. D., \& Heyrani, F. (2014). Examination of auditor acceptance of dysfunctional behavior using a heuristic model. International Journal of Academic Research in Accounting, Finance and Management Sciences, 4(1), 41-51.

Ghozali I. 2011. Aplikasi Multivariat dengan Program IBM SPSS 19. Semarang:, Badan Penerbit Universitas Diponegoro.

Hartman, LP, \& Desjardins, J. (2011). Etika bisnis: Pengambilan keputusan untuk integrasi pribadi dan tanggung jawab sosial. (A. Maulana, Penyunt., \& D. Pujiati, Penerj.) Jakarta: Erlangga. 
Hickss, J. A., \& King, L. A. (2008). Religious commitment and positive mood as information about meaning in life. Journal of Research in Personality, 42(1), 43-57.

Indarto, S. L. (2011). Analisis Faktor-Faktor Yang Mempengaruhi Penghentian Prematur Atas Prosedur Audit. Dinamika Sosial Ekonomi, 7(2), 197-210.

International Labour Organization. (2012). Convergences: Decent work and social justice in religious traditions: A handbook.

Kay, A. C., Gaucher, D., McGregor, I., \& Nash, K. (2010). Religious belief as compensatory control. Personality and Social Psychology Review, 14(1), 37-48.

Marietza, F. (2010). Analyzing the influence of internal and external factors on auditor's dysfunctional behavior in accounting public firm at Surabaya-Indonesia. MIICEMA2010-182 Malaysia-Indonesia International Conference on Economics, Management and Accounting 2010,371-384

McCullough, M. E., \& Willoughby, B. L. (2009). Religion, self-regulation, and self-control: Associations, explanations, and implications. Psychological bulletin, 135(1), 69.

McGuire, S. T., Omer, T. C., \& Sharp, N. Y. (2011). The impact of religion on financial reporting irregularities. The Accounting Review, 87(2), 645-673.

Nadirsyah, N., \& Zuhra, I. M. (2009). Locus of control, time budget pressure dan penyimpangan perilaku dalam audit. Jurnal Telaah dan Riset Akuntansi, 2(2), 104-116.

Paino, H., Ismail, Z., \& Smith, M. (2014). Modelling dysfunctional behaviour: Individual factors and ethical financial decision. Procedia-Social and Behavioral Sciences, 145, 116-128.

Paino, H., Pahang, U. T. M., Ismail, Z., \& Smith, M. (2011). Dysfunctional audit behaviour: The effects of employee performance, turnover intentions and locus of control. Journal of Modern Accounting and Auditing, 7(4), 418-423.

Paino, H., Thani, A., Syid, S. I. Z. (2011). Organisational and professional commitment on dysfunctional audit behaviour. British Journal of Arts and Social Sciences 1(2), 94-105

Parliament of the World's Religions. (1993). Declaration Toward a Global Ethic. Chicago

Robbins, P. S., \& Judge, A. T. (2013). Organizational Behavior (15th Ed.). New Jersey: Pearson Prentice Hall.

Rotter, J. B. (1966). Generalized expectancies for internal versus external control of reinforcement. Psychological Monographs: General and Applied, 80(1), 1-28.

Shamsudin, F. M., Chauhan, A., \& Kura, K. M. (2012). Self-control as a moderator of the relationship between formal control and workplace deviance: A proposed framework. Australian journal of business and management research, 2(6), 32-39.

Shapeero, M., Chye Koh, H., \& Killough, L. N. (2003). Underreporting and premature sign-off in public accounting. Managerial Auditing Journal, 18(6/7), 478-489.

Shyan Fam, K., Waller, D. S., \& Zafer Erdogan, B. (2004). The influence of religion on attitudes towards the advertising of controversial products. European Journal of Marketing, 38(5/6), 537-555.

Siagian, S. P. (2012). Teori Motivasi dan Aplikasinya. Jakarta: Rineka Cipta.

Silaban, A. (2011). Pengaruh multidemensional komitmen profesional terhadap perilaku audit disfungsional. Jurnal Akuntansi \& Auditing 8 (1), 1-11.

Suddaby, R., Gendron, Y., \& Lam, H. (2009). The organizational context of professionalism in accounting. Accounting, Organizations and Society, 34(3), 409-427.

Ulum, A. S. (2005). Pengaruh orientasi etika terhadap hubungan antara time pressure dengan perilaku premature sign-off prosedur audit. MAKSI, 5(2), 194-212. 